\title{
Study of Antibacterial Effect of Cerium Oxide Nanoparticles on Escherichia Coli Microorganism
}

\author{
SHOUKAT ALI NOONARI*, UMAIR AFTAB**, IMTIAZ ALI SOOMRO**, BILAL AHMED \\ SOOMRO**, AND AKBER ALI PIRZADA*
}

RECEIVED ON 16.10.2017 ACCEPTED ON 17.08.2018

\begin{abstract}
In the present work antibacterial effect of NCO (Nano-Cerium Oxide) particles on E.Coli (Escherichia Coli) Bacteria was studied. NCO (Nano Cerium Oxide) particles were synthesized via microwave induced combustion method. XRD (X-Ray Diffraction), SEM (Scanning Electron Microscope) and FTIR (Fourier Transform Infrared Spectroscopy) characterized. NCO particles. Using Scherrer equation it was noted that NCO particles of 14-25 $\mathrm{nm}$ size were produced. The SEM and XRD results showed that size of NCO particles was decreased with increasing synthesization time. Synthesization time played vital role on the size of NCO particles.
\end{abstract}

It was also noted that antibacterial action of NCO particles is size dependent. Antibacterial study through disc diffusion method revealed that NCO particles enhanced the efficiency of Amikin Grasil, Terivid and spraxin drugs against the E.Coli bacteria appreciably.

Key Words: Nano Cerium Oxide, Escherichia Coli, Antimicrobial Analysis.

\section{INTRODUCTION}

$\mathrm{C}$ erium oxide commonly known as ceric oxide or ceria is most abundant rare earth metal oxide. NCO particles are currently being used as antibacterial catalyst, oxygen sensor and in production of oxidation resistant coating [1-3]. Due to small size, NCO particles possess unique physical and chemical properties such as high magnetic moment, large conductivity and extremely high complexation reactivity [3-4]. NCO particles are insoluble in water and has slightly hygroscopic nature which means it can absorb some amount of $\mathrm{CO}_{2}$ and moisture from the atmosphere [5].
Some microorganisms are harmful for human body and cause diseases in different ways such as E.Coli bacteria, staphylococcus aureus, and pseudomonas [6]. NCO particles are pale-yellow- white powder. NCO particles has FCC crystal structure and is highly stronger than other rare earth oxides such as $\mathrm{Bi}_{2} \mathrm{O}_{3}$ (Bismuth Dioxide), $\mathrm{ThO}_{2}$ (Thorium Dioxide) and $\mathrm{ZrO}_{2}$ (Zirconia) [7-8]. Many methods are used to prepare NCO particles such as microwave energy, hydrothermal synthesis, sol-gel methods, precipitation and emulsion methods. Microwave induced method is simple, rapid and efficient method as compared with other conventional methods [9-10].

Authors E-Mail: (shoukat.ali@isra.edu.pk, umair.aftab@faculty.muet.edu.pk, imtiaz.soomro@admin.muet.edu.pk, bilal.ahmed@isra.edu.pk, akber.ali@isra.edu.pk)

* Department of Mechanical Engineering, Isra University, Hyderabad, Pakistan.

** Department of Metallurgy \& Materials Engineering, Mehran University of Engineering \& Technology, Jamshoro, Pakistan.

This is an open access article published by Mehran University Research Journal of Engineering and Technology, Jamshoro under the CC by 4.0 International License. 
E.Coli bacteria is a gram-negative microorganism found in digestive tracts of humans as well as animals and cause haemolytic uremic syndrome, bloody diarrhea and kidney failure which can cause to death [11]. NCO particles are used with different antibiotics to inhibit the growth of E.Coli bacteria. NCO particles material is one of important example of a metal oxide nanomaterial with many biomedical applications [12-14]. Previous research work mostly focused on effect of NCO particles on staphylococcus aureus and pseudomonas microorganism The present study aims to investigate the antibacterial effect of $\mathrm{NCO}$ particles on E. Coli bacteria which has not been found in literature.

\section{EXPERIMENTAL}

\subsection{Synthesis of NCO Particles}

Synthesis of NCO from cerium nitrate was carried out using microwave technique. Consumables and nonconsumables materials used for synthesis of $\mathrm{NCO}$ particles were analytical grade and used without purification. The synthesis of NCO particles involved microwave combustion of redox mixtures of cerium nitrate as an oxidizing reactant and urea as a reducing agent.

The redox mixture containing $0.25 \mathrm{~g}$ cerium nitrate (Merck Company, USA) and $0.12 \mathrm{~g}$ of urea (Fatima Group) was diluted with $2 \mathrm{ml}$ distilled water, stirred for $10 \mathrm{~min}$ using sonicator set at $50 \mathrm{~Hz}$ and finally filtered and heated into microwave oven at 600 watts for different time intervals.

\subsection{Characterization}

Different techniques were used for characterization of NCO particles. XRD (Model: Bruker-X8) used for the determination of mineralogy of NCO particles. All samples were scanned from $20-80^{\circ}$ at $2 \%$ min speed and 40 Kilovolt and EVA(Enhanced Visual Apparatus) software were used for the pattern of XRD. Surface morphology of NCO particles the NCO particles was examined under SEM (Flex SEM 1000). By using Scherrer Equation $(T=K \lambda / \beta \cos \theta)$ for the determination of particle size, full width half maximum was measured. Phase transformation in cerium nitrate taken place at different microwave heating time intervals was identified by using FTIR (Model IRTRACER 100) technique examined surface morphology of NCO particles.

\subsection{Disc Diffusion Method}

The resistance E.coli for the antibiotic drugs namely Amikin Grasil, Enoxabid, Spraxin, Velosef, Terivid, and Ceftriaxone in absence and presence of $\mathrm{NCO}$ was in vitro studied using disc diffusion method. The behaviour of E.Coli bacteria against the antibiotic drugs was studied in absence and presence of NCO particles by using disc diffusion method. For the cultivation of microorganism, media was prepared by adding $7 \mathrm{~g}$ of nutrient agar in $50 \mathrm{ml}$ distilled water. The solution was heated at $121^{\circ} \mathrm{C}$ in autoclave for $15 \mathrm{~min}$. Thereafter, specific dose of NCO particles was added and properly mixed in nutrient agar solution. After that, nutrient agar solution with or without NCO particles was equally poured in six petri dish and left for $5 \mathrm{~min}$ to dry. E.Coli bacteria was applied on dried nutrient agar with help of cotton swab. Small disc of $6 \mathrm{~mm}$ diameter impregnated with antibiotic medicine loaded with $30 \mathrm{mg}$ was placed in the centre of the petri dish. The cultured petri dishes were incubated at $37^{\circ} \mathrm{C}$ for 24 hours.

\subsection{Measurement of Inhibition Zone}

The diameter of inhibition zone was measured using Vernier caliper and compared with Kirby-Bauer chart to determine susceptibility of bacteria to NCO particles. Susceptibilty of bacteria may be high, intermediate or poor. The size of inhibition zone given in Table 1 was used to consider susceptibility of E. coli bacteria with or without addition of NCO particles. 


\section{RESULTS AND DISCUSSION}

\subsection{Phase Analysis of Nano Cerium Oxide particles}

Phase analysis of NCO was determined by XRD. XRD pattern of NCO particles synthesized at different time intervals is shown in Fig. 1. The Fig. 1 shows the characteristics peaks of NCO particles at $2 \theta=28.5,33.40$, 47.49 and 56.50. It can be observed in Fig. 1 that with increasing the synthesis time, peaks become more prominent. No any other peak was developed only pure NCO particles was developed.

\subsection{FTIR Analysis}

FTIR patterns of NCO particles synthesized for different time intervals are shown in Fig. 2. Peaks revealed that bands at $722,852,1073,1200,1300,1491 \mathrm{~cm}^{-1}$ are representing the NCO particles. Whereas bands at 1585 $\mathrm{cm}^{-1}$ and onward are indicating the nitrogen based compounds like amino acids $\left(\mathrm{NH}_{3}\right)$ azoxy compound $(\mathrm{N}-$ $\mathrm{O})$ and amides (N-H). The difference in absorbance value of peaks indicates that time of synthetization play vital role on the exertion of nitrogen from lattices of NCO particles. For the maximum exertion amount of nitrogen $40 \mathrm{~min}$ is the optimal time.

TABLE 1. DIAMETER OF INHIBITION ZONE

\begin{tabular}{|c|c|c|c|}
\hline No. & $\begin{array}{c}\text { Diameter of Inhibition Zone } \\
(\mathrm{mm})\end{array}$ & $\begin{array}{c}\text { Susceptibility of } \\
\text { Organism }\end{array}$ & Explanation \\
\hline 1. & +2 & Susceptible (S) & $\begin{array}{c}\text { Bacteria is not resistant to specific antibiotic; therefore its growth was } \\
\text { inhibited by the drug effectively. }\end{array}$ \\
\hline 2. & $+1-2$ & Intermediate (I) & $\begin{array}{c}\text { Bacteria is less resistant to specific antibiotic, therefore its growth could } \\
\text { inhibited to some extent by the drug. }\end{array}$ \\
\hline 3. & $0-1$ & Resistant (R) & $\begin{array}{c}\text { Bacteria is resistant to specific antibiotic, therefore its growth } \\
\text { could not inhibited by the drug effectively. }\end{array}$ \\
\hline
\end{tabular}

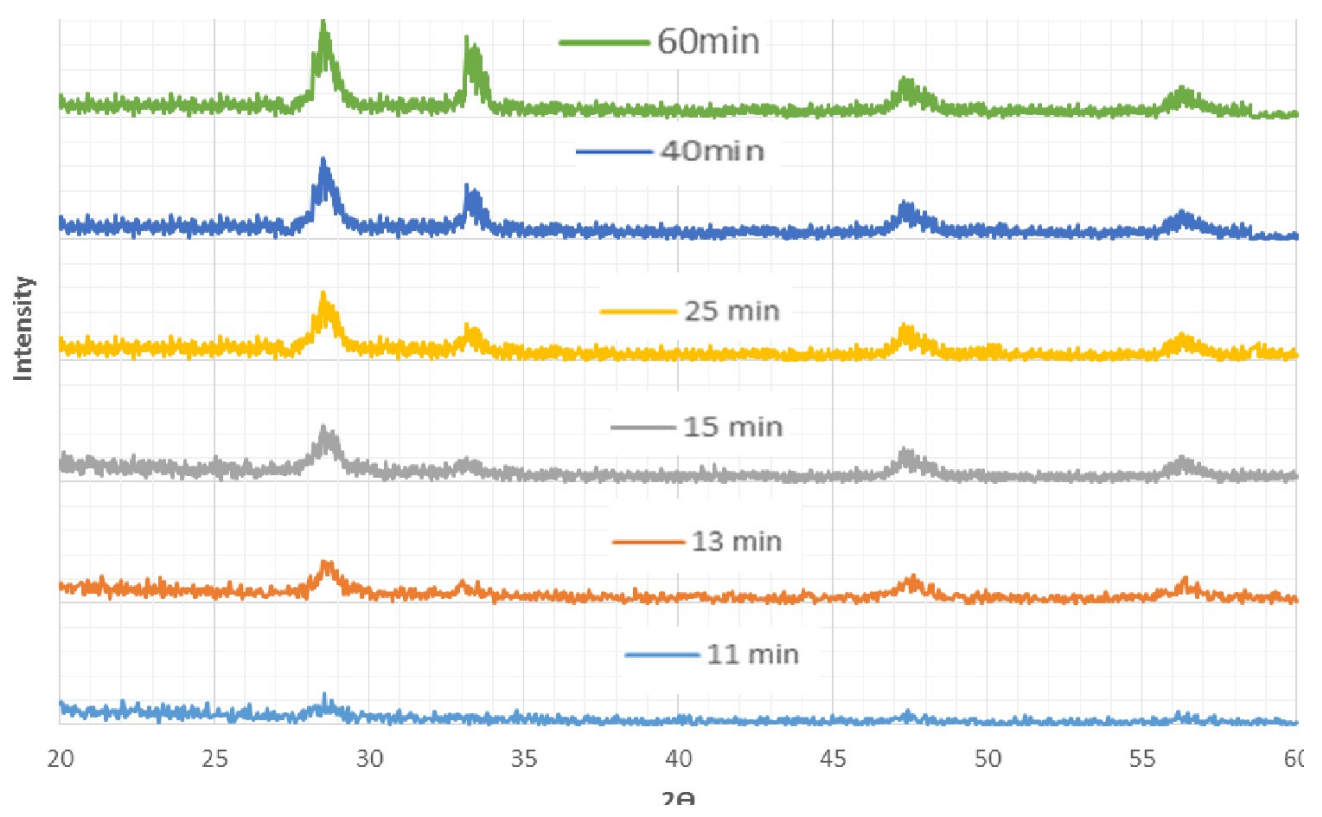

FIG. 1. XRD PATTERN OF NCO 


\subsection{Particle Size Analysis of NCO}

Particle size of NCO particles was determined by scherrer equation $\left(\mathrm{d}_{\mathrm{XRD}}=0.9 \lambda / \beta \cos \theta\right)$ given in Table 2 . It can be seen in table that average crystalline size of NCO particles ranging from 25.9-13.9 $\mathrm{nm}$. Substantial decrease in size of NCO particles was occurred with increasing the synthesis time.
During synthesization of NCO when we increase synthesis time size of particles are decreased due to dissipation of particles.

\subsection{Morphology of NCO Particles}

Morphology of NCO particles was investigated using SEM. SEM images shown in Fig. 3(a-c) indicate porous

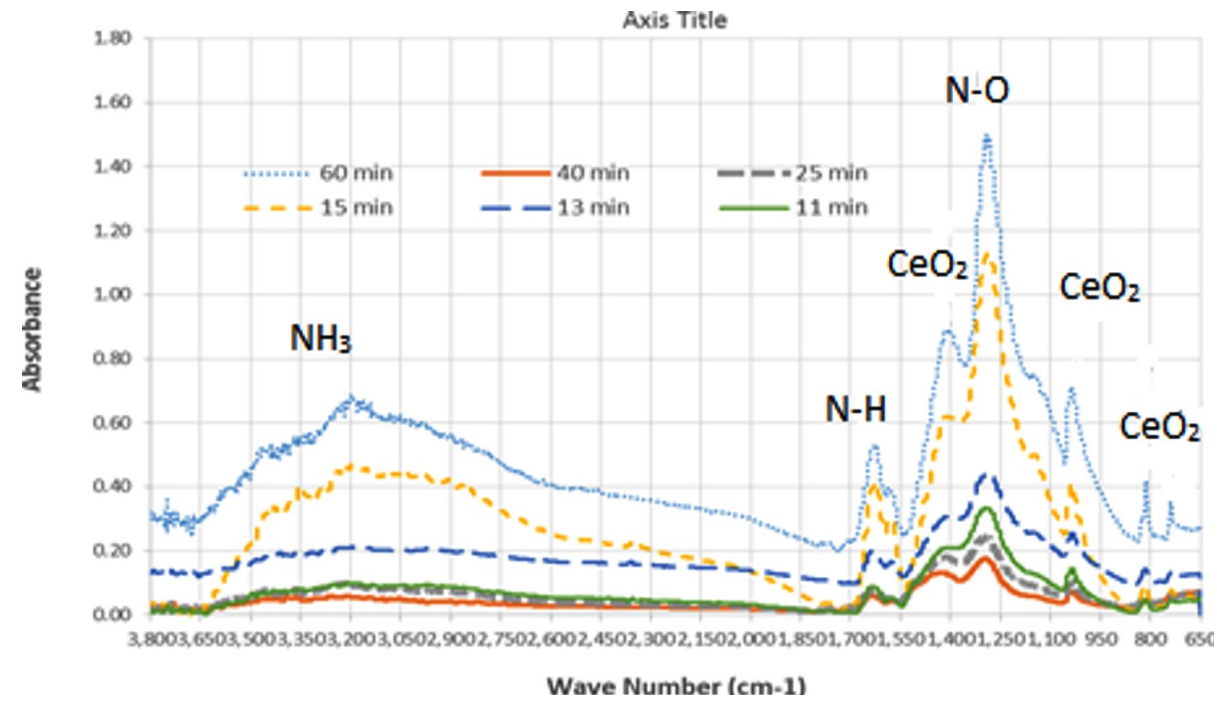

FIG. 2. FTIR PATTERN OF NCO

TABLE 2. PARTICLE SIZE ANALYSIS OF NCO USING SCHERRER EQUATION

\begin{tabular}{|c|c|c|c|c|}
\hline $\begin{array}{l}\text { NCO Synthesis Time } \\
\text { (min) }\end{array}$ & $\begin{array}{c}\text { FWHM } \\
\text { (Deg) }\end{array}$ & $\begin{array}{c}2 \\
(\mathrm{Deg})\end{array}$ & $\begin{array}{l}\text { Wavelength } \\
\text { (A) }\end{array}$ & $\begin{array}{l}\text { Particle Size } \\
\quad(\mathrm{nm})\end{array}$ \\
\hline \multirow{4}{*}{11} & 0.77 & 28.5 & 1.5406 & 10.65 \\
\hline & 0.287 & 33.4 & 1.5406 & 28.58 \\
\hline & 0.213 & 47.4 & 1.5406 & 38.50 \\
\hline & \multicolumn{3}{|c|}{ Average } & 25.9 \\
\hline \multirow{4}{*}{13} & 0.522 & 28.5 & 1.5406 & 5.24 \\
\hline & 0.982 & 33.4 & 1.5406 & 8.35 \\
\hline & 0.25 & 47.4 & 1.5406 & 32.81 \\
\hline & \multicolumn{3}{|c|}{ Average } & 15.46 \\
\hline \multirow{4}{*}{15} & 0.778 & 28.5 & 1.5406 & 10.54 \\
\hline & 0.548 & 33.4 & 1.5406 & 14.97 \\
\hline & 0.498 & 47.4 & 1.5406 & 16.47 \\
\hline & \multicolumn{3}{|c|}{ Average } & 13.9 \\
\hline
\end{tabular}

Mehran University Research Journal of Engineering \& Technology, Volume 38, No. 3, July, 2019 [p-ISSN: 0254-7821, e-ISSN: 2413-7219] 
structure of NCO particles. It can be seen in Fig. 3(a-c) that with increasing the synthetization time porosity is increased and irregularity in NCO particles was decreased and Fig. 3(d) indicated that well regular spherical particles were developed having size $100 \mathrm{~nm}$.

\subsection{Antimicrobial Analysis of NCO Particles on E.Coli Bacteria}

Antimicrobial action of NCO particles was investigated against E.Coli bacteria. The antimicrobial action of NCO particles synthesized at 15,25 and 40 min time intervals were evaluated respectively. The inhibition values given in Table 3 indicates that $20 \mathrm{mg} / \mathrm{ml} \mathrm{NCO}_{15 \min }$ along with 30 mg of antibiotic drugs namely Terivid, Velosef, Amikin Grasil, Spraxin and Enoxabid failed to inhibit against the growth of E.Coli bacteria.

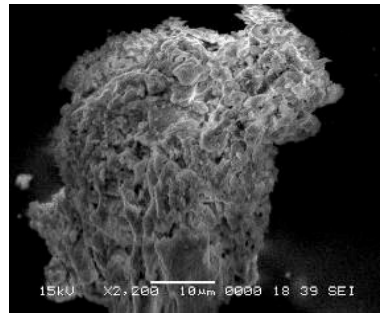

FIG 3(a). NCO SYNTHESIS IN 11 MIN

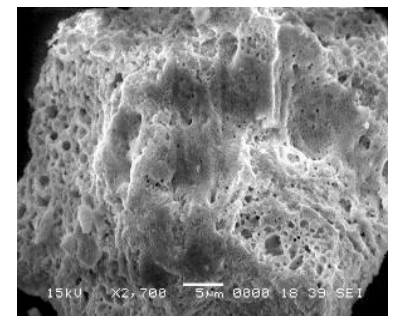

FIG 3(b). SYNTHESIS IN 13 $M I N$

Antimicrobial activity of $\mathrm{NCO}_{25 \min }$ particles results given in Table 3 indicates that diameter of inhibition zone was increased to some extent when terivid and amikin grasil drugs were supplemented with $\mathrm{NCO}_{25 \text { min }}$ particles. Moreover, the efficiency of, velosef, spraxin and enoxabid antibiotics could not improve with the addition of $\mathrm{NCO}_{25 \min }$ particles.

Antimicrobial analysis with $\mathrm{NCO}_{40 \min }$ particles are quite encouraging as compared to results with $\mathrm{NCO}_{15 \min }$ particles and $\mathrm{NCO}_{25 \min }$ particles. It can be seen in Table 3 that size of inhibition zone in case of grasil, terivid and spraxin was substantially increased with the addition of $\mathrm{NCO}_{40 \text { min }}$ particles.

It is appreciable to note that with addition of $\mathrm{NCO}_{40 \mathrm{~min}}$ particles inhibition zone could not increase rather decreased

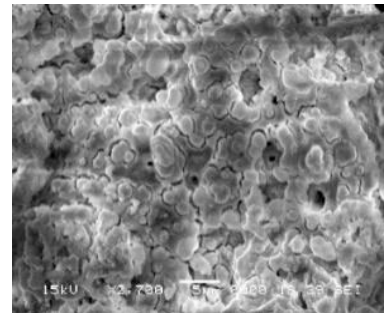

FIG 3(c). SYNTHESIS IN 15 $M I N$

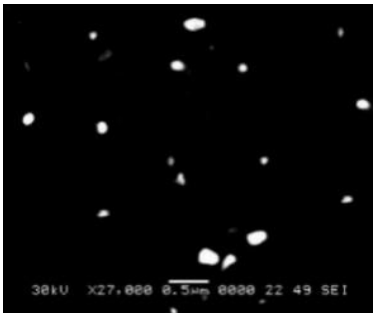

FIG 3(d). NCO SPHERICAL PARTICLE

TABLE 3. ANTIMICROBIAL ACTIVITY OF NCO

\begin{tabular}{|c|c|c|c|c|c|c|}
\hline $\begin{array}{l}\text { NCO Dose } \\
(20 \mathrm{mg} / \mathrm{ml})\end{array}$ & \multicolumn{2}{|c|}{$\mathrm{NCO}_{15 \text { min }}$} & \multicolumn{2}{|c|}{$\mathrm{NCO}_{25 \min }$} & \multicolumn{2}{|c|}{$\mathrm{NCO}_{40 \text { min }}$} \\
\hline $\begin{array}{l}\text { Antibiotic } \\
(30 \mathrm{mg} / \mathrm{l})\end{array}$ & $\begin{array}{l}\text { Inhibition Zone } \\
\qquad(\mathrm{mm})\end{array}$ & $\begin{array}{l}\text { Susceptibility/ } \\
\text { Resistance }\end{array}$ & $\begin{array}{l}\text { Inhibition Zone } \\
\qquad(\mathrm{mm})\end{array}$ & $\begin{array}{l}\text { Susceptibility/ } \\
\text { Resistance }\end{array}$ & $\begin{array}{l}\text { Inhibition Zone } \\
(\mathrm{mm})\end{array}$ & $\begin{array}{l}\text { Susceptibility/ } \\
\text { Resistance }\end{array}$ \\
\hline Amikin Grasil & \multirow{6}{*}{0} & \multirow{6}{*}{ Resistance } & +2.5 & \multirow{6}{*}{ Resistance } & +3.5 & \multirow{3}{*}{ Susceptibility } \\
\hline Terivid & & & +2 & & +5 & \\
\hline Spraxin & & & 0.5 & & +3.5 & \\
\hline Velosef & & & 0 & & +1 & \multirow{3}{*}{ Resistance } \\
\hline Enoxabid & & & 0.5 & & 1.5 & \\
\hline Ceftriaxone & & & 0 & & 0 & \\
\hline
\end{tabular}

Mehran University Research Journal of Engineering \& Technology, Volume 38, No. 3, July, 2019 [p-ISSN: 0254-7821, e-ISSN: 2413-7219] 
like $\mathrm{NCO}_{15 \min }$ particles and $\mathrm{NCO}_{25 \min }$ particles. The evidence of decrease or increase in the inhibition zone was also can see in images of the diffusion disks after $24 \mathrm{~h}$ incubation period. Fig. 4(a-c) illustrates the images of few of the diffusion disks and demonstrate where and when the inhibition zone was increased with the effect of NCO particles.

Results of the paper compared with literature:

The XRD pattern of $\mathrm{CeO}_{2}$ nanoparticles is shown in Fig. 5. The XRD pattern was scanned from 1080 degrees with the scan rate $2 \theta \mathrm{min}^{-1}$. The XRD profile confirmed the polycrystalline nature of the cerium oxide nanoparticles. The high intensity peaks were observed at 28.53, 33.09, 47.5, and 56.26. The diffraction peaks in these XRD spectra indicates the pure cubic fluorite structure.

(2) Crystallite size was obtained by using Scherrer equation (Fig. 6):

The FTIR spectrum of NOC nanoparticles is shown in Fig. 7. The spectrum was recorded in the wave number range of $400-4000 \mathrm{~cm}^{-1}$.

Explanation for all results, why?
During synthesis of NCO particles, it was observed that by increasing the synthesis time.

- $\quad$ Particle size is decreased,

- Irregular particles were converted to regular particles and

- Nitrogen based compounds were also eliminated.

NCO particles were synthesis by mixing of cerium nitrate and urea. Synthesis on $15 \mathrm{~min}$ when product of cerium oxide was manufactured due to traces of nitrogen from cerium nitrate was still present in manufactured cerium oxide, that nitrogen bonds were identified by FTIR technique(nitrogen is the nutrient of bacteria). Then by increasing the synthesis time nitrogen based compounds were eliminated. NCO particles synthesis on $40 \mathrm{~min}$ is become effective and by this growth of E.coli bacteria was inhibited.

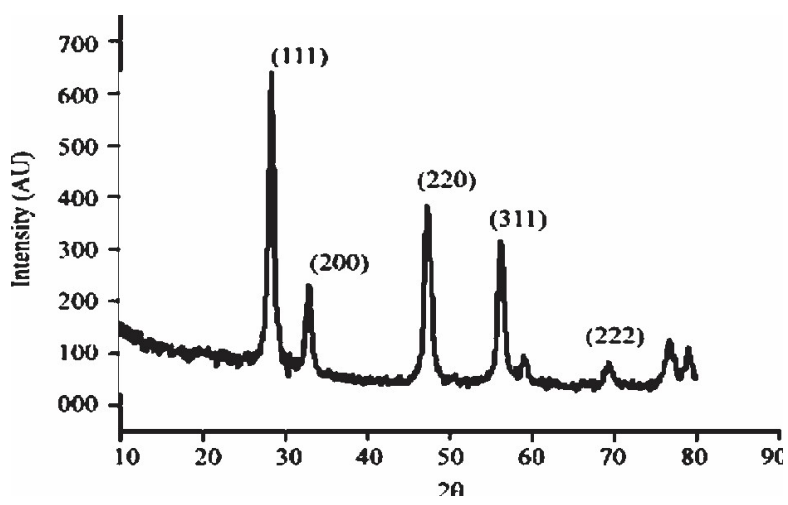

FIG. 5. XRD PATTERN OF NCO PARTICLES

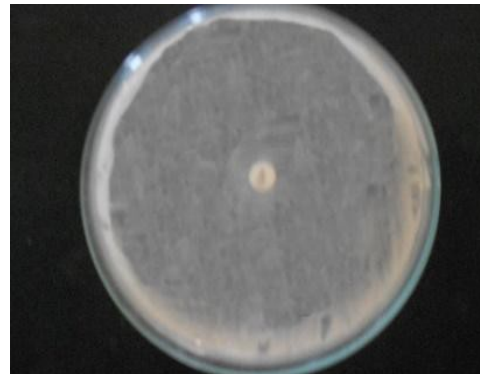

FIG. 4(a). $20 \mathrm{mg} / \mathrm{ml} \mathrm{NCO}{ }_{15 \min }$

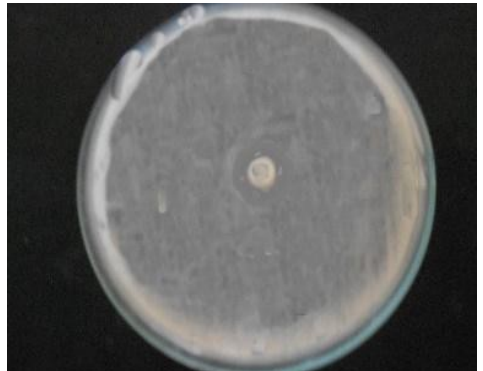

FIG. 4(b). $20 \mathrm{mg} / \mathrm{ml}$ of $\mathrm{NCO}_{25 \mathrm{mi}}$

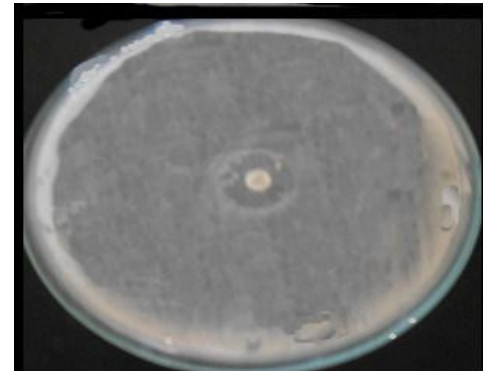

FIG. 4(c). $20 \mathrm{mg} / \mathrm{ml} \mathrm{NCO}{ }_{40 \mathrm{~min}}$

Mehran University Research Journal of Engineering \& Technology, Volume 38, No. 3, July, 2019 [p-ISSN: 0254-7821, e-ISSN: 2413-7219] 


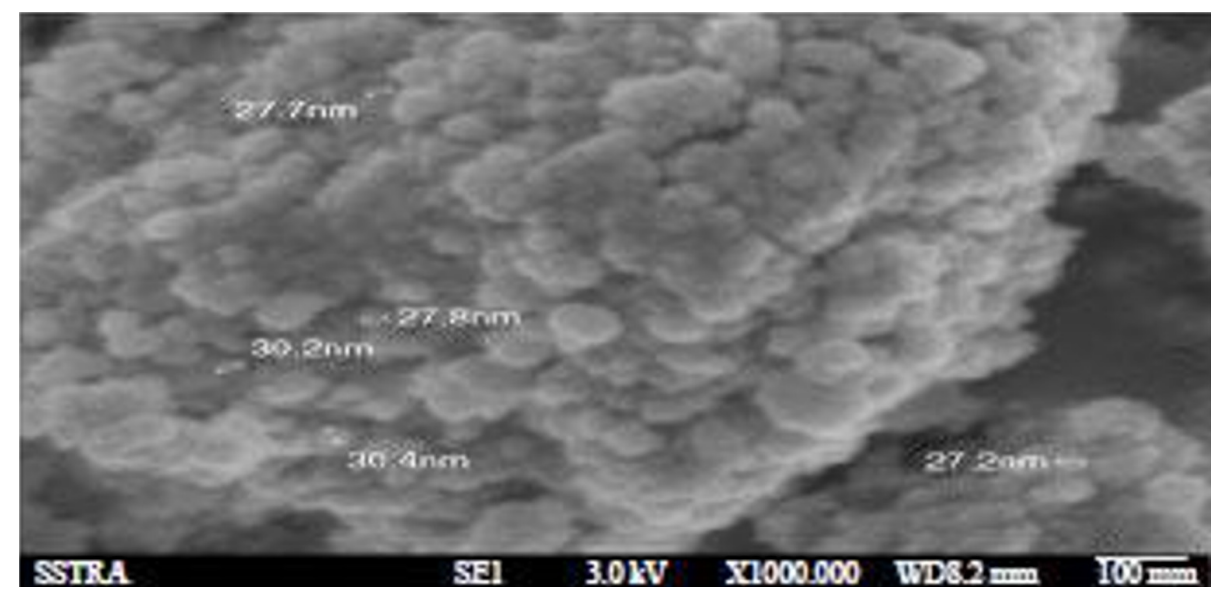

FIG 6. SEM OF CERIUM OXIDE NANOPARTICLES

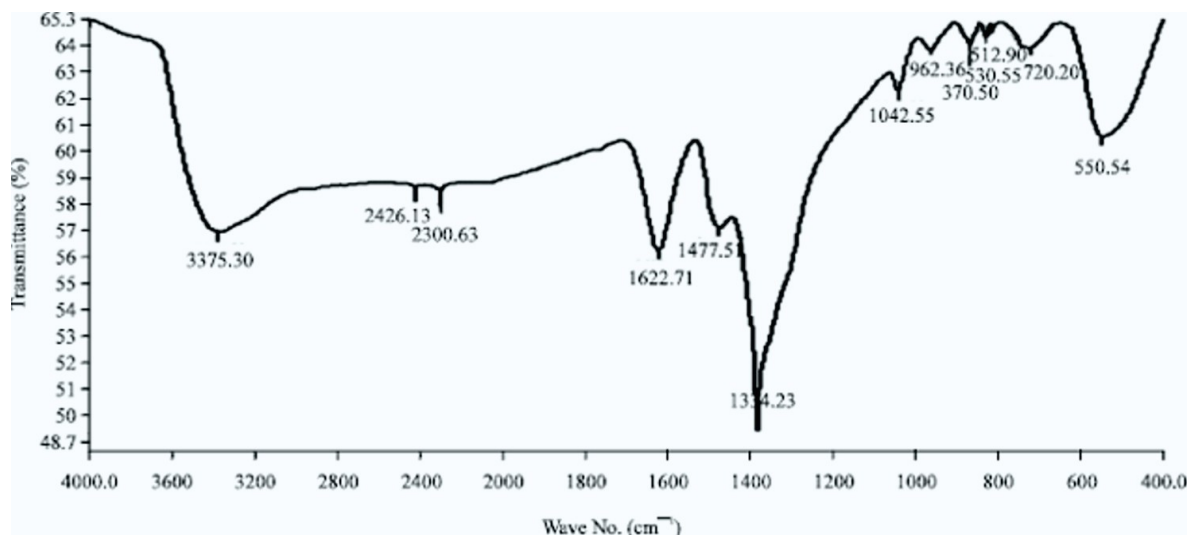

FIG. 7. FTIR SPECTRUM OF CERIUM OXIDE NANOPARTICLES

\section{CONCLUSION}

This work investigated the antibacterial effect of NCO particles. Synthetization time plays a vital role by increasing the synthesis time nitrogen based compounds are reduced from NCO particles and size of particles is also decreased. Scanning electron microscopy study also revealed that by rough and irregular particles were converted to regular spherical shaped particles by increasing synthetization time. FTIR technique is more effective as compared to XRD technique, since nitrogen based compounds in NCO particles product was only identified in the FTIR pattern. Antibacterial action of NCO particles evaluated along with antibiotic drugs revealed that $\mathrm{NCO}_{40 \mathrm{~min}}$ particles is more effective as compared to $\mathrm{NCO}_{15 \min }$ particles and $\mathrm{NCO}_{25 \text { min }}$ particles.

\section{ACKNOWLEDGEMENT}

Authors acknowledge Department of Mechanical Engineering, Isra University, Hyderabad, and Department of Metallurgy \& Materials Engineering, Mehran University of Engineering \& Technology, Jamshoro, Pakistan, for motivating and supporting for the successful completion of this research work. 


\section{REFERENCES}

[1] Aramaki, K., "Treatment of Zinc Surface with Cerium (III) Nitrate to Prevent Zinc Corrosion in Aerated 0.5 M NaCl", Journal of Corrosion Science, Volume 43, No. 11, pp. 2201-2215, 2001.

[2] Babenko, L.P., Zholobak, N.M., Shcherbakov, A.B., Voychuk, S.I., Lazarenko, L.M., and Spivak, M.Y., "Antibacterial Activity of Cerium Colloids against Opportunistic Microorganisms in Vitro", Mikrobiologicheskii Zhurnal, [ISSN: 0201-8462], Volume 74, No. 3, pp. 54-62, 2012.

Chen, B.H., Suresh Babu, K.,kumar.A, M., Tsai, T.Y., Kao, T.H., and Stephen Inbaraj, B., "Cytotoxicity and Antibacterial Activity of Gold-Supported Cerium Oxide Nanoparticles", International Journal of Nanomedicine, Volume 9, No.1, pp. 5515-5531, 2014.

Crespo, J., García-Barrasa, J., Lopez-de-Luzuriaga, J.M., Monge, M., Olmos, M.E., Saenz, Y., and Torres, C., "Organometallic Approach to Polymer-protected Antibacterial Silver Nanoparticles: Optimal Nanoparticle Size-Selection for Bacteria Interaction", Journal of Nanoparticle, Volume 14, No. 12, pp. 1-13, 2012.

$\mathrm{Fu}$, Y.P., and Lin, C.H., "Preparation of $\mathrm{Y}_{2} \mathrm{O}_{3}$-Doped $\mathrm{CeO}_{2}$ Nano Powders by Microwave-Induced Combustion Process", Journal of Alloys and Compounds, Volume 89, No. 1-2, pp. 165-168, 2005.

[6] Hilaire, S., Luo, L., Rechberger, F., Krumeich, F., and Niederberger, M., "Microwave-Assisted Nonaqueous Synthesis of Doped Ceria Nanoparticles Assembled Into Flakes", Journal of Nanoparticle, Volume 640. No. 5, pp 733-737, 2014.

Soykal,I.I. Sohn, H., Bayram, B., Gawade, P., Snyder, P.M., Stephen, E.L., Oz, H., and Ozkan, S,U., "Effect of Microgravity on Synthesis of Nano Ceria”, Journal Article of Catalysts, Volume 5, No. 3, pp. 1306-1320, 2015 .
[8] Lin, K.S., and Chowdhury, S., "Synthesis, Characterization, and Application of 1D Cerium Oxide Nanomaterials", International Journal of Molecular Sciences, Volume 11, No. 9, pp. 3226-3251, 2010.

[9] Mogensen, M., Sammes, N.M., and Tompsett, G.A., "Physical, Chemical and Electrochemical Properties of Pure and Doped Ceria", Journal of Solid State Ionics, Volume 129, No. 1-4, pp. 63-94, 2000.

[10] Negahdary, M., Mohseni, G., Fazilati, M., Parsania, S., Rahimi, G., Rad, S., and Rezaei-Zarchi, S., "The Antibacterial Effect of Cerium Oxide Nanoparticles on Staphylococcus Aureus Bacteria", Annals of Biological Research, Volume 3, No. 7, pp. 3671-3678, 2012.

[11] Odonkor, S.T., and Addo, K.K., "Bacteria Resistance to Antibiotics: Recent Trends and Challenges", International Journal of Biological \& Medical Research, Volume 2, No. 4, pp. 1204-1210, 2011.

[12] Panacek, A., Kvítek, L., Prucek, R., Kolar, M., Vecerova, R., Pizurova, N., Sharma, V.K.; Nevecna, T., and Zboril, R., "Silver Colloid Nanoparticles: Synthesis, Characterization, and Their Antibacterial Activity”, Journal of Physical Chemistry, Volume 110, No. 33, pp. 16248-16253, 2006.

[13] Sahu, T., Bisht, S.S., Das, K.R., and Kerkar, S., "Nanoceria: Synthesis and Biomedical Applications", Current Nanoscience, Volume 9, No. 3, pp. 1-6, 2013.

[14] Santos, C. dos., Passos Farias, I.; Reis Albuquerque, A., Silva, P., Costa, O.G., and Sampaio, F., “Antimicrobial Activity of Nano Cerium Oxide (IV) $\left(\mathrm{CeO}_{2}\right)$ Against Streptococcus Mutans”, BMC Procedings, Volume 8, No. 4, pp. 48, 2014. 